\title{
Physical Fitness and Psychological Wellness of Saudi Engineering Students as Related to Academic Achievement
}

\author{
Abdullah O. Bafail, Madbuli H. Noweir, Ibrahim M. Jomoah, \\ and Abdulrahman M. Basahel \\ Department of Industrial Engineering, Faculty of Engineering, \\ King Abdulaziz University, Jeddah, Saudi Arabia
}

Abstract. The present study was conducted on a stratified random sample of 100 students of the College of Engineering of King Abdulaziz University (KAU), representing the Saudi university students, with the objectives of: (a) studying the impact of students' physical fitness and psychological wellness on their academic achievement, (b) identifying effective related factors improving or limiting students' achievement and, (c) presenting a practical model of optimal physical fitness and psychological wellness for Saudi students. Data of the study are needed by the planners in the Kingdom of Saudi Arabia (KSA) to harmonize and optimize the presented services related to the educational process, and to have utmost output of them.

Each of the selected students was interviewed for his health and psychological status, performed intelligence test and subjected to fit-test measurements, followed by testing his academic records and recording his Grade Points Average (GPA).

Analysis of variance for the effect of the tested students' 57 variables on their GPAs revealed highlighting 20 of them as the most influential variables, and further testing the significance of their effects indicated that the main academic effective factors on students' academic achievement include: students' levels of intelligence and the student's background education of the holy Quran, English language and computer practices; meanwhile, the "relatively exceeding" numbers of courses attended by students through the academic semester have a negative impact on their GPAs. The need of the students for the university stipend represents the main studied economic factor which has impact on their academic achievement. The main effective cultural, social and health factors include: the students' involvements in community scientific, cultural and social 


\begin{abstract}
events, the "favourable" social relations within the family, the "higher families" economic status, and the "favourable" dietary habits. All these factors might, however, partially have masked the anticipated impact of the students' health fitness on their academic achievement. Therefore, it has been recommended to further study this subject with widening its scope, and increasing the number of studied students.
\end{abstract}

Keywords: Physical fitness, Psychological wellness, Academic achievement, Saudi Arabia, University students.

\title{
1. Introduction
}

The primary responsibility of the academic institutions is to foster the academic achievement. They can do that by providing a high quality of instructional program, but also by paying attention to students' health. ${ }^{[1]}$ Although the government of the Kingdom of Saudi Arabia (KSA) has launched tremendous socio-economic programs in the last decades, particularly in health and education, where free education is provided to male and female students, and huge numbers of schools and 25 governmental universities and 8 private universities have been established, yet no studies have been carried out to investigate the impact of health and psychological wellness on the process of education. Such data are needed by the planners in the country to harmonize and optimize the presented services related to the educational process and to have utmost output of them. The present study has been intended to present some data and conclusions in this respect.

Since decades ago, scientists have been studying the impact of the physical and psychological fitness on the process of learning. For example, there are substantial reports that present a clear connection between components of well-health such as good nutrition, physical activity, psychological wellness and learning. ${ }^{[1]}$ Meanwhile, the association between physical activity among school-aged children and adolescent and their academic outcome has been relatively recently presented by Taras $(2005)^{[2]}$ who reviewed the state of research on this subject (9 studies and reports). ${ }^{[3-11]}$ The review demonstrated that there may be some short-term improvements (such as concentration). Moreover, it has been commented elsewhere ${ }^{[12]}$ that good nutrition and physical fitness are hallmarks of high achievement and good health in children and adolescents, and, consequently, affect their growth and learning. Further studies have been carried out recently in different countries on the impact of physical and psychological factors on 
academic achievement. For example, a longitudinal study of 166 boys and 128 girls $^{[13]}$ indicated that prosocialness (viz: cooperating, helping, sharing and counseling) has a strong positive impact on later academic achievement and social performance among the tested students. Also, in a study of a large sample of Chinese children and adolescents at 9, 13, and 16 years of age, ${ }^{[14]}$ it was found that peer groups were highly homogeneous on academic achievement. Moreover, the relationship between work characteristics, students' wellbeing and performance, was assessed in a sample of 825 Portuguese university students'. Results, suggested that levels of students satisfaction with academic life have a direct impact on student performance ${ }^{[15]}$.

However, in a recent study of large students' sample $(\mathrm{N}=4,475)$ in Germany ${ }^{[16]}$ of the relationship between multiple dimensions of selfconcept, personality, wellbeing, and academic outcomes (school grades, test score, course selection), it has been demonstrated that:

a. The self-concept factors have a highly differentiated pattern of relations with the personality factors and academic outcomes; and

b. Self-esteem, personality and wellbeing factors explained only small amounts of variance in academic outcomes, and support for their incremental validity, after controlling for self-concept factors, was weak.

Furthermore, genetic and ethnic origins have been suggested to affect students' academic achievement based on results from the first national study on the impact of ethnic differences on academic achievement among U.S. children of various ages ${ }^{[17]}$. However, some physical impairments, particularly, visual defects, and student's social handicap have been reported to affect students' academic achievements $^{[18-21]}$.

Definitions and performance standards of physical fitness vary. For example, physical fitness can be defined as "The ability to meet life's demands and still have enough energy to respond to unplanned events". Another definition is: "The ability to carry out daily tasks with vigor and alertness, without undue fatigue, and with ample energy to enjoy leisuretime pursuits and to meet unforeseen emergencies" ${ }^{[22]}$. Other definitions, which do not vary much from those stated above are also stated ${ }^{[23]}$.

The Physical fitness include five components, which are ${ }^{[24]}$ : 
1. Cardio-respiratory endurance; also called aerobic endurance or aerobic fitness, which indicates the ability to supply and use oxygen, over a period of time and in sufficient amounts, to perform normal and unusual activities (stability and endurance of heart and lungs).

2. Muscular strength: is the amount of force a muscle can exert for one repetition.

3. Muscular endurance: the muscle's ability to continue submaximal contraction against resistance.

4. Flexibility: the range of motion around a joint or the ability to move limbs gracefully and efficiently.

5. Body Composition: the relationship between fat weight and lean body mass (mass of the non-fatty component of the body).

Many factors affect physical fitness and include ${ }^{[25]}$ :

1. Maturation ${ }^{[25]}$

2. Nutrition ${ }^{[25,26]}$ and environment (physical and social) ${ }^{[25,27-29]}$.

3. Heredity ${ }^{[25,30-32]}$.

4. Physical activity ${ }^{[31,32]}$ (exercise).

Heredity has a strong impact on body fitness, and human's heredity has an impact on four components of health-related physical fitness, that $\operatorname{are}^{[25]}$ :

- Morphological component: obesity (body fat content), regional fat distribution, visceral fat and bone density.

- Muscular component.

- Cardio-respiratory component: associated with cardiac, vascular and respiratory functions, and

- Metabolic component.

Psychological wellness is the health of mind and emotion (selfconcept) of humans. Psychological wellness is a general perception that one will experience positive outcomes to the events and circumstances (e.g. economic status) of life. The psychological or mental health can be defined in both positive and negative terms. Positively, it can be viewed as a state of being in which an individual is stable and balanced. Human beings function at three levels: hence the balance is 3-dimentional and 
involves being in harmony with oneself, the human society around him, and fulfilling the orders and commands of the Creator to attain His pleasure. Negatively, it can be looked at as the presence of mental or psychological problems. Unlike physical health, mental and psychological health is difficult to define exactly because of inability to define and measure in a concrete way as is done in physical sciences. Also, psychological health can be defined as a state of emotional and psychological wellbeing in which an individual is able to use his / her cognitive and emotional capabilities, function in society, and meet the ordinary demands of everyday life. Many factors are anticipated to affect students' psychological wellness and may include ${ }^{[33]}$ :

1. Physical status (e.g. age, health condition, physical activity).

2. Physical environment (e.g. housing, crowding, weather).

3. Psychological status including; self-efficacy, attitudes and beliefs.

4. Social environment, including:

a. Family situation (number of siblings, whether parents are divorced, if the child stays with one or both of the parents, other relatives or foster parents, and whether the family or the child experiences lack of money) and student's marital status.

b. School and universities conditions (number of students, satisfaction with school and teachers, as well as own results, total time spent at school, and school absence because of headache).

c. Friends (whether the student has a close-friend, feelings of loneliness, and experience of being bullied).

d. Leisure-time activities (number of sports and other activities, time spent outdoors, watching TV, using computers, doing homework or playing with friends).

e. Lifestyle (sleeping and eating habits, addiction or other drugs).

f. Religious conviction, reading of Quran and laudation, which are very important factors anticipated to have good impact on students' psychological wellness.

The scope of this study includes the engineering students of King Abdulaziz University (KAU) as a sample representing Saudi students. It generally aims to investigate the impact of some parameters affecting 
students' health wellness (physical and psychological) on their academic achievement. The specific objectives include:

1. Studying the impact of students' physical fitness and psychological wellness on their academic achievement.

2. Identifying the factors improving physical and psychological wellness, that are of main impact on the academic achievement, in an endeavor to have them included in the whole schooling procedures.

3. Identifying the factors limiting physical and psychological wellness that should be controlled in the schooling procedures.

4. Presenting a practical model of optimal physical fitness and psychological wellness for Saudi students.

\section{Methodology}

\subsection{Study Population}

In order to select a representative sample of KAU engineering students, the students' population was obtained from the Deanship of Academic Affairs and distributed as related to the scientific departments and the students' study years. A stratified random sample (SRS) of $\mathrm{N}=100$ students was selected representing students' different departments and study years as described elsewhere. ${ }^{[34]}$ Initially one half of the students $(\mathrm{N}=50)$ had been selected and examined as described in the next section. The results of the physical fitness measurement of these students were analyzed using MINITAB software, particularly evaluating the normality test for each measurement, which proved that their distributions were all normal. The sample size was, therefore, computed assuming $\alpha=0.05$ and confidence interval $(\mathrm{CI})=95 \%$. The computed proper sample size $(\mathrm{N})$ for each test of the Fit-Kit Measurements ranged from 31 to 89 subjects and, consequently, indicating that the selected size of the sample $(\mathrm{N}=100)$ was satisfactory.

\subsection{Data Collection}

A study form was prepared and tested for collecting data related to selected students. The form is divided into three sections including:

a. Student's interview for his personal, physical and psycho-social status.

b. Student's physical fitness measurement. 
c. Student's academic achievement.

\subsubsection{Students' Interview for Personal, Physical and Psycho-Social Status}

The questionnaire which was prepared to interview the selected students is mainly intended to collect students' information on:

a. Basic information (e.g. name, identification, addresses, channels of communication, gender, age).

b. Social status (e.g. marriage, place of birth, housing, social stability, parents and their education, cultural level, economic level, leisure time sports, skills, hobbies).

c. Health status (e.g. family health history, smoking, previous and present health complaints).

d. Psychological history (e.g. previous and current complaints, addiction).

e. Intelligence Test (ten question of intelligence have been selected from the forty questions used by the International Society of High Intelligence Questions (IQ) Arabic Individuals Website) ${ }^{[35]}$.

The questionnaire had been tested on interviewing 20 students of the sample before being revised and approved for its final use. The students were personally interviewed by one of the researchers only, using this questionnaire, in order to avoid any bias that may arise by using different interviewers.

\subsubsection{Measurement of Students' Physical Fitness}

The selected students were subjected to measuring their physical fitness using the physical fitness kit (Fit-Kit) of Lafayette, USA (Cat. No. 47903) ${ }^{[36]}$. The battery of tests in the kit include: height $(\mathrm{cm})$, shoulder width $(\mathrm{cm})$, blood pressure $(\mathrm{mm} \mathrm{Hg})$, grip-strength $(\mathrm{kg})$, peak-flow $(1 / \mathrm{min})$, sit and reach $(\mathrm{cm})$, vertical-jump height $(\mathrm{cm})$, weight $(\mathrm{kg})$, skinfold (mm, \% normal), shoulder flexibility ( $\mathrm{cm}$, score), hand-eye coordination ( $\mathrm{sec})$, bicycle ergo-meter (heart rate) $(\mathrm{ml} / \mathrm{kg} / \mathrm{min})$ and blood cholesterol (mmol/l). The used Fit-Kit group consists of a comprehensive method to screen individuals on components of fitness, either health or performance related. The series of the tests included in the Kit (the FitKit protocol) are easy to carry out, and it takes 30-45 minutes to complete them. The fitness as assumed by the designer of the Fit-Kit group of tests is defined as: "the ability to work with vigor and pleasure 
without undue fatigue, with energy left for enjoying hobbies and recreational activities and for meeting unseen emergencies".

\subsubsection{Students' Academic Achievement:}

The records of the Deanship of Admission and Registration were reviewed as related to the examined students for their GPA. This parameter was introduced into the sector of student's academic achievement in the study form.

\subsection{Data Analysis}

The data were entered in MS-Excel sheet for basic analysis. Minitab 14 was used for analyzing the data and producing charts. Multiple regression analysis technique (ANOVA table) and correlation matrix were used to find the range effect of all variables on GPA and to identify the highlighted variables that have most influence on GPA. A significance level $\alpha$ of 0.05 was assumed for all tests. P-value and correlation coefficient were taken as indicators to which variables have high effect on GPA based on $(\mathrm{P}-\mathrm{value}<0.05)$ and $(\mathrm{r}>0.5) .{ }^{[37]}$ Finally, the significance of the effect of each level of the variables was tested by using t-test.

\section{Results and Discussion}

\subsection{Demographic Characteristics of the Study Population}

The demographic characteristics of the studied students' sample are presented in Table 1, more than three quarters of the students (77\%) are aged between 21 and 24 years, with only $11 \%$ of them younger than 21 years and $12 \%$ aged 25 years or more. More than one half of the students $(52 \%)$ are single and living with their families, while $30 \%$ of them are single and either living alone (17\%), or with colleagues (13\%), and $18 \%$ of them are married, mostly living independently (with their wives and children only: $16 \%$ ), with a few living with their main families (2\%). As a consequence to that, $71 \%$ of the students consider themselves stable in their lives, while $29 \%$ are not stable. Meanwhile, the 18 married students mostly have very good relation with their wives (14/18: $77.8 \%$ ), with their wives' relatives $(11 / 18: 61.1 \%)$ and with their relatives as related to their wives (12/18: 66.7\%), as well as having very good relations with their children (11/18: 61\%), the rest of students evaluated these relations as good. 
Table 1. Demographic characteristics of the examined students' sample.

\begin{tabular}{|c|c|c|}
\hline Serial & Characteristics & $\begin{array}{c}\text { Distribution } \\
(100 \text { Students) }\end{array}$ \\
\hline \multirow[t]{7}{*}{1} & Age (year): & \\
\hline & $<21$ & 11 \\
\hline & 21 & 21 \\
\hline & 22 & 29 \\
\hline & 23 & 12 \\
\hline & 24 & 15 \\
\hline & $25+$ & 12 \\
\hline \multirow[t]{6}{*}{2} & Living Status: & \\
\hline & Single and living alone & 17 \\
\hline & Single and living with colleagues & 13 \\
\hline & Single and living with his family & 52 \\
\hline & Married \& living with his wife \& children only & 16 \\
\hline & Married and living with his main family & 2 \\
\hline \multirow[t]{3}{*}{3} & Evaluation of Living Stability: & \\
\hline & Stable & 71 \\
\hline & Not Stable & 29 \\
\hline \multirow[t]{3}{*}{4} & Marital Status: & \\
\hline & Married & 18 \\
\hline & Not Married & 82 \\
\hline \multirow[t]{3}{*}{$\mathrm{a}$} & Relation with Wife: & \\
\hline & very good & 14 \\
\hline & good & 4 \\
\hline \multirow[t]{3}{*}{$\mathrm{b}$} & Relation with Wife's Relatives: & \\
\hline & very good & 11 \\
\hline & good & 7 \\
\hline \multirow[t]{3}{*}{$\mathrm{c}$} & Relation with Student's Relatives as Related to his Wife: & \\
\hline & very good & 12 \\
\hline & good & 6 \\
\hline \multirow[t]{3}{*}{$\mathrm{d}$} & Children's Status: & \\
\hline & very good & 11 \\
\hline & good & 7 \\
\hline \multirow[t]{6}{*}{5} & $\begin{array}{l}\text { Nature of Father's Work (or the Person in Charge in case of } \\
\text { Father's Death): }\end{array}$ & \\
\hline & Top jobs & 30 \\
\hline & Businessman & 27 \\
\hline & Humble jobs & 33 \\
\hline & Salesman & 9 \\
\hline & Doesn't work & 1 \\
\hline \multirow[t]{7}{*}{6} & $\begin{array}{l}\text { Level of Father's Education (or the Person in Charge in case } \\
\text { of Father's Death: }\end{array}$ & \\
\hline & Postgraduate & 12 \\
\hline & Graduate & 34 \\
\hline & Intermediate & 34 \\
\hline & Fundamental & 11 \\
\hline & Read / write & 2 \\
\hline & Illiterate & 7 \\
\hline
\end{tabular}


Table 1. Contd.

\begin{tabular}{|c|c|c|}
\hline Serial & Characteristics & $\begin{array}{l}\text { Distribution } \\
\text { (100 Students) }\end{array}$ \\
\hline \multirow[t]{5}{*}{7} & Nature of Mother's Work: & \\
\hline & Top jobs & 4 \\
\hline & Business lady & 6 \\
\hline & Humble jobs & 16 \\
\hline & Doesn't work & 74 \\
\hline \multirow[t]{7}{*}{8} & Level of Mother's Education: & \\
\hline & Postgraduate & 5 \\
\hline & Graduate & 19 \\
\hline & Intermediate & 28 \\
\hline & Fundamental & 32 \\
\hline & Read / write & 6 \\
\hline & Illiterate & 10 \\
\hline \multirow[t]{5}{*}{9} & Status of the Family: & \\
\hline & The father is married to student's mother only & 80 \\
\hline & $\begin{array}{l}\text { The father has other wives and every wife has a private housing } \\
\text { for her and her children }\end{array}$ & 2 \\
\hline & The mother is dead / divorced & 14 \\
\hline & $\begin{array}{l}\text { The father is married to a wife other than the mother and the } \\
\text { student is living with them }\end{array}$ & 4 \\
\hline \multirow[t]{5}{*}{10} & Number of Brothers: & \\
\hline & $\leq 3$ & 22 \\
\hline & 4 to 5 & 41 \\
\hline & 6 to 10 & 26 \\
\hline & 11 to 20 & 11 \\
\hline \multirow[t]{4}{*}{11} & Brothers' Education: & \\
\hline & All brothers are literate or in various educational stages & 77 \\
\hline & Some are literate and others are illiterate & 22 \\
\hline & No brothers & 1 \\
\hline \multirow[t]{4}{*}{12} & Family Housing: & \\
\hline & Private & 79 \\
\hline & Shared with Relatives & 13 \\
\hline & Others (Rent) & 8 \\
\hline \multirow[t]{4}{*}{13} & $\begin{array}{l}\text { Evaluation of Population Intensity in Housing (No. of } \\
\text { Family Members / No. of Rooms): }\end{array}$ & \\
\hline & Excellent & 53 \\
\hline & Average & 33 \\
\hline & Crowded & 14 \\
\hline \multirow[t]{5}{*}{14} & Evaluation of Housing Disturbances: & \\
\hline & None & 59 \\
\hline & $\begin{array}{l}\text { Living away from family and / or having problems with family } \\
\text { members }\end{array}$ & 11 \\
\hline & Expensive accommodations (Rent) & 7 \\
\hline & $\begin{array}{l}\text { Overcrowded neighborhood, insufficient living space, and / or } \\
\text { neighbors' disturbances }\end{array}$ & 23 \\
\hline
\end{tabular}


Table 1. Contd.

\begin{tabular}{|c|c|c|}
\hline Serial & Characteristics & $\begin{array}{c}\text { Distribution } \\
\text { (100 Students) }\end{array}$ \\
\hline \multirow[t]{6}{*}{15} & Evaluation of Family Relations (Maximum Score = 30): & \\
\hline & $\leq 5$ & 3 \\
\hline & 6 to 10 & 14 \\
\hline & 11 to 15 & 46 \\
\hline & 16 to 20 & 24 \\
\hline & $21+$ & 13 \\
\hline \multirow[t]{5}{*}{16} & Evaluation of Car Ownership Status (i.e. Brand and Year) & \\
\hline & Excellent & 15 \\
\hline & Intermediate & 42 \\
\hline & Less than intermediate & 27 \\
\hline & Student does not own car & 16 \\
\hline \multirow[t]{5}{*}{17} & Dependence on University Monthly Allowance: & \\
\hline & Used in recreation purposes only & 19 \\
\hline & Used in educational requisites only & 34 \\
\hline & Used in educational requisites and living purposes & 39 \\
\hline & $\begin{array}{l}\text { No allowance (i.e. exceeding allowed period for payment of } \\
\text { allowances) }\end{array}$ & 8 \\
\hline \multirow[t]{6}{*}{18} & Family's Share in Living and Education Expenses: & \\
\hline & $\begin{array}{l}\text { The student lives with the family and it bears all his expenses of } \\
\text { living \& education }\end{array}$ & 25 \\
\hline & $\begin{array}{l}\text { The student lives alone and the family bears all his expenses of } \\
\text { living and education }\end{array}$ & 5 \\
\hline & $\begin{array}{l}\text { The student lives alone and the university allowance shares in } \\
\text { expenses of living and education }\end{array}$ & 25 \\
\hline & $\begin{array}{l}\text { The student is married and family supports his fees for } \\
\text { education and living and recreation expenses }\end{array}$ & 18 \\
\hline & $\begin{array}{l}\text { The student lives with the family and family does not support } \\
\text { all his expenses of living, education and recreation }\end{array}$ & 27 \\
\hline \multirow[t]{6}{*}{19} & Student's Preference to Pay Fees for Proper Education: & \\
\hline & Strongly agree & 37 \\
\hline & Agree & 19 \\
\hline & Neutral & 22 \\
\hline & Disagree & 10 \\
\hline & Strongly disagree & 12 \\
\hline \multirow[t]{3}{*}{20} & Work of Student's beside his Study: & \\
\hline & Study only & 85 \\
\hline & Work and study & 15 \\
\hline
\end{tabular}


Table 1. Contd.

\begin{tabular}{|c|l|c|}
\hline Serial & \multicolumn{1}{|c|}{ Characteristics } & $\begin{array}{c}\text { Distribution } \\
\text { (100 Students) }\end{array}$ \\
\hline $\mathbf{2 1}$ & $\begin{array}{l}\text { Researcher's Classification of Reasons of Choosing the } \\
\text { College of Engineering: }\end{array}$ & \\
\hline & Encouragement and desire of family and / or friends & 32 \\
\hline & Personal desire for engineering study & 29 \\
\hline & $\begin{array}{l}\text { Reputation of the college and / or various departments and } \\
\text { anticipated society appreciation }\end{array}$ & 15 \\
\hline & Good chance of recruitment in future and society services \\
\hline 22 & $\begin{array}{l}\text { Does the Economic Outcome Represent an Incentive to the } \\
\text { Student's Enrollment in the College of Engineering } ?\end{array}$ & 24 \\
\hline & Yes & 71 \\
\hline $\mathbf{2 3}$ & No & $\begin{array}{l}\text { Does the Parents' Care Present an Incentive to the } \\
\text { Student's Enrollment in the College of Engineering ? }\end{array}$ \\
\hline & Yes & 79 \\
\hline & No & 21 \\
\hline
\end{tabular}

More than one half of the students $(57 \%)$ are of favorable socioeconomic strata as indicated from the nature of their fathers' work, since $30 \%$ of the fathers occupy top jobs and $27 \%$ of them are businessmen, while one third of the fathers $(33 \%)$ have humble jobs, $5 \%$ are salesmen and only one father (1\%) does not work. These socio-economic strata are further demonstrated by presenting the education levels of both the students' fathers and mothers, since $46 \%$ of the fathers have high education (Bachelor degree), with 12\% having postgraduate education (Doctoral and/or Master degrees), and 34\% of them have high schools education, $13 \%$ having basic education and only $7 \%$ are illiterate. Also, $24 \%$ of the mothers hold high education degrees (Bachelor) with $5 \%$ having postgraduate degrees (Doctoral and/or Master), 28\% having high schools education, $38 \%$ having basic education, and only $10 \%$ are illiterate. However, because of the current community constraints that do not often encourage the work of wives, $74 \%$ of the mothers do not have jobs or occupations, while only $10 \%$ have top jobs or are business ladies, and $16 \%$ have humble jobs. Meanwhile, $80 \%$ of the fathers are married, only, to student's mother (one wife), while only 4 students are living with step-mothers and $14 \%$ of the students' mothers are dead or divorced. However, most students belong to large families, since $78 \%$ of them have four or more brothers (and sisters), while $11 \%$ of them have 11 to 20 brothers (and sisters). But mostly all the brothers are literate $(76 \%$ all brothers, and $22 \%$ some brothers). 
The students' family housing further demonstrates the students' favorable socio-economic status, since $79 \%$ of the families live in private housings, and the population housing intensity is excellent with $53 \%$ of the families, and average in $33 \%$ of them, while no housing disturbances occur in $59 \%$ of the housings.

Meanwhile, $84 \%$ of the students own cars, where $15 \%$ are excellent as related to car brand and year of production, $42 \%$ are intermediate, and only $16 \%$ of the students do not have private cars. Also, mostly one half of the families completely bear their students' living and education expenses (48\%: $25 \%, 5 \%$ and $18 \%)$, while share these expenses in the rest of students $(25 \%$ and $27 \%)$. That is why $56 \%$ of the students prefer paying fees for proper education, (strongly agree: $37 \%$ and agree: $19 \%$ ), while $22 \%$ of them disagree. However, $39 \%$ of the students commented that they use the university monthly allowances in educational requisites and living purposes, while $34 \%$ of them use it for the educational requisites; moreover, $15 \%$ of the students work beside their study to gain living expenses including the $8 \%$ who do not receive university allowances.

As related to the motivations of the students in being enrolled in the College of Engineering, their interview indicated that $32 \%$ of the students were encouraged for that by their families and/or their friends, while $29 \%$ stated that they had the desire for studying engineering, $15 \%$ for the reputation of the college and/or some of the departments, as well as the anticipated society appreciation, and $24 \%$ for believing in having good chance in recruitment in future occupational and society services. However, $71 \%$ of them believe that the anticipated economic outcome represent incentive to the students enrollment in the College of Engineering, while $79 \%$ of them, also, believe that their parents' care represent another incentive.

\subsection{Students' Educational Characteristics}

The educational characteristics of the studied students are presented in Table 2. A fair proportion of the students (19\%) passed the test of foreigners in English language (TOFEL), while 47\% studied English at language institutes, beside their study at their schools, and 34\% of them studied the language at school only. It followed that $27 \%$ of the students have been evaluated "excellent" as related to their English language education, while $21 \%$ as "good", $32 \%$ as "fair" and $20 \%$ as "weak". 
Meanwhile, $21 \%$ of the students studied computer sciences and practice at technical institutes before admission into the university, while some of the others practiced computer use on their own. Consequently, $25 \%$ of the students have been evaluated as "excellent" in their computer applications, while $36 \%$ as "good", $25 \%$ as "fair" and $14 \%$ as "weak". Also, the education of students by free readings and acquaintances and of their use of internet became somewhat close, since they have been evaluated as "excellent" in $12 \%$ and $14 \%$ and as "very good" in $25 \%$ and $29 \%$, respectively; however, considerable proportion have not considered free reading (39\%), while only $2 \%$ do not use the Internet. Meanwhile, the evaluation of students practice of sports is better than their free reading and use of Internet, since $35 \%$ of them have been evaluated as "excellent" in the sports practice, $16 \%$ as "very good", $24 \%$ as "good" and $25 \%$ as "weak" including the $16 \%$ who have not been practicing sports.

As related to student's interest in their studies, more than one half of them (54\%) strictly attend their lectures and $27 \%$ are oftenly attending, while $19 \%$ are rarely attending their lectures. Surprisingly, only $4 \%$ of the students are interested in all their courses, while $37 \%$ are interested in most courses, $48 \%$ interested in some and $11 \%$ in a few of them. Mostly similarly, only $6 \%$ of the students like all their instructors, $25 \%$ like most, $42 \%$ like some, and $26 \%$ like a few of them; while $15 \%$ like all their colleagues, $49 \%$ like most, $28 \%$ like some, and $8 \%$ like a few of them.

The students', evaluation of the courses presented to them, and their class status, revealed that $56 \%$ of them believe they have many courses, $75 \%$ believe their courses are long, $67 \%$ believe that instructor requirements of their courses are many, and $92 \%$ believe that their study burdens are heavy. On the other hand, $80 \%$ of the students believe that the educational methods applied in class and the preparation for the courses are convenient, $65 \%$ of them believe that the number of students in the class rooms are acceptable, and $42 \%$ of them have interest in outof-college local and International events.

It may be stressed that a fair proportion of the students (46\%) study their subjects more than 3 hours daily, including 10\% studying 5 or more hours; meanwhile, $35 \%$ of them memorize Quran, either all of it $(6 \%)$ or parts of it $(29 \%)$. 
Table 2. Students' educational characteristics.

\begin{tabular}{|c|c|c|}
\hline Serial & Characteristics & $\begin{array}{l}\text { Distribu- } \\
\text { tion (100 } \\
\text { Students) } \\
\end{array}$ \\
\hline \multirow[t]{4}{*}{1} & $\begin{array}{l}\text { Status of Student's Practice of English Language Beside } \\
\text { Studying at School, Before Admission into University: }\end{array}$ & \\
\hline & Obtained TOFEL & 19 \\
\hline & Studied at language institutes & 47 \\
\hline & No additional practice besides studying at school & 34 \\
\hline \multirow[t]{5}{*}{2} & Evaluation of Student's Level of English Language Education: & \\
\hline & Excellent & 27 \\
\hline & Good & 21 \\
\hline & Fair & 32 \\
\hline & Weak & 20 \\
\hline \multirow[t]{3}{*}{3} & Status of Computer Practice Before Admission into University: & \\
\hline & Studying computer science and practice in technical institutes & 21 \\
\hline & No practice on computer before admission into university & 79 \\
\hline \multirow[t]{5}{*}{4} & Evaluation of Student's Level in Computer Applications: & \\
\hline & Excellent & 25 \\
\hline & Good & 36 \\
\hline & Fair & 25 \\
\hline & Weak & 14 \\
\hline \multirow[t]{6}{*}{5} & Evaluation of Student's Free Readings and Acquaintances: & \\
\hline & Excellent & 12 \\
\hline & Very good & 25 \\
\hline & Good & 19 \\
\hline & Weak & 5 \\
\hline & Doesn't read & 39 \\
\hline \multirow[t]{6}{*}{6} & Evaluation of Student's Use of Internet: & \\
\hline & Excellent & 14 \\
\hline & Very good & 29 \\
\hline & Good & 35 \\
\hline & Weak & 20 \\
\hline & Doesn't use & 2 \\
\hline \multirow[t]{6}{*}{7} & Evaluation of Student's Practice of Sports: & \\
\hline & Excellent & 35 \\
\hline & Very good & 16 \\
\hline & Good & 24 \\
\hline & Weak & 9 \\
\hline & Doesn't exercise sports & 16 \\
\hline \multirow[t]{4}{*}{8} & Student's Obligation in Attending Lectures: & \\
\hline & Strict attendance & 54 \\
\hline & Often attending & 27 \\
\hline & Rare attendance & 19 \\
\hline \multirow[t]{5}{*}{9} & Student's Interest in his Courses: & \\
\hline & All & 4 \\
\hline & Most & 37 \\
\hline & Some & 48 \\
\hline & A few & 11 \\
\hline
\end{tabular}


Table 2. Contd.

\begin{tabular}{|c|c|c|}
\hline Serial & Characteristics & $\begin{array}{c}\text { Distribu- } \\
\text { tion (100 } \\
\text { Students) }\end{array}$ \\
\hline \multirow[t]{6}{*}{ 10- } & The Student Likes his Instructors: & \\
\hline & All & 6 \\
\hline & Most & 25 \\
\hline & Some & 42 \\
\hline & A few & 26 \\
\hline & None & 1 \\
\hline \multirow{5}{*}{11} & The Student Likes his Colleagues: & \\
\hline & All & 15 \\
\hline & Most & 49 \\
\hline & Some & 28 \\
\hline & A few & 8 \\
\hline \multirow[t]{3}{*}{12} & Student's Evaluation of the Number of the Courses Attended: & \\
\hline & ( & 58 \\
\hline & Fair & 42 \\
\hline \multirow[t]{3}{*}{13} & $\begin{array}{l}\text { Student's Evaluation of the Length of the Courses which he } \\
\text { Attends: }\end{array}$ & \\
\hline & Long & 75 \\
\hline & Fair & 25 \\
\hline \multirow[t]{3}{*}{14} & $\begin{array}{l}\text { Student's Evaluation of the Educational Methods and } \\
\text { Preparation of the Courses which he Attends }\end{array}$ & \\
\hline & Convenient & 80 \\
\hline & Inconvenient & 20 \\
\hline \multirow[t]{3}{*}{15} & $\begin{array}{l}\text { Student's Evaluation of the Instructors' Requirements in the } \\
\text { Courses which he Attends: }\end{array}$ & \\
\hline & Many & 67 \\
\hline & Fair & 33 \\
\hline \multirow[t]{3}{*}{16} & $\begin{array}{l}\text { Student's Evaluation of his Study Burden (assignments, tests, } \\
\text { others): }\end{array}$ & \\
\hline & Heavy & 56 \\
\hline & Normal & 44 \\
\hline \multirow[t]{3}{*}{17} & Student's Evaluation of the Students' Number in Classroom: & \\
\hline & Many & 35 \\
\hline & Acceptable & 65 \\
\hline \multirow[t]{3}{*}{18} & $\begin{array}{l}\text { Student's Involvement or Interests in Out-of-College Events } \\
\text { (e.g. Being Busy with Local \& International Events): }\end{array}$ & \\
\hline & Yes & 42 \\
\hline & No & 58 \\
\hline \multirow[t]{5}{*}{19} & Student's Average Daily Study Hours: & \\
\hline & $\leq 1$ & 21 \\
\hline & $\overline{2}$ & 33 \\
\hline & 3 to 4 & 36 \\
\hline & $5+$ & $\frac{5}{10}$ \\
\hline \multirow[t]{5}{*}{20} & Student's Memorization of Quran: & \\
\hline & Memorizing all Quran & 6 \\
\hline & Memorizing parts of Quran & 29 \\
\hline & Only reading Quran & 49 \\
\hline & Rarely reading Quran & 16 \\
\hline
\end{tabular}




\subsection{Students' Health and Nutrition Characteristics}

The students' health and nutrition characteristics are shown in Table 3. More than one half (58\%) of the students do not smoke, while $23 \%$ smoke cigarettes, $14 \%$ smoke "shishah" (i.e. water filtered smoking of molassed tobacco), and 5\% of them smoke both the cigarettes and shishah. However, most of the smokers have relatively low smoking index (SI), since $33.3 \%$ of the smokers $(14 / 42)$ have SI of 5 or less, $40.5 \%(17 / 42)$ have SI of $6-15$, and $25.2 \%$ (11/42) have SI of 16 or more, which might be attributed to their relative young age, and consequently, their relative short smoking durations.

The investigation and analysis of the students diets intake during their most recent week revealed that only $36 \%$ of them have balanced diets, and only $9 \%$ of them are deficient in calories, while $16 \%$ are deficient in protein, $21 \%$ deficient in vitamins and minerals, and $18 \%$ of them have unbalanced diets. This situation needs urgent and strong action to improve the nutritional status of the students, mainly by their education of good dietary habits. The importance of this might be visualized by reviewing the examined students' dietary habits. For example, only $11 \%$ of the students have always their breakfast at home and two-thirds of them (67\%) never, or sometimes, have it there. Their intakes of dinner and supper are mostly similar to the intake of the breakfast, however, to slightly better extents. This conclusion is further supported by the students' response of having their meals away from home and the evaluation of their favorable foods, where $99 \%$ of them have their meals away from home, either always $(19 \%)$, oftenly $(39 \%)$ or sometimes (40\%), and only $23 \%$ of them have healthy diets, $44 \%$ have unhealthy diets, and the rest's $(33 \%)$ diets might be healthy to some extent.

The analysis of the subjective description of the students for the health conditions of their different systems indicates that:

- $60 \%$ of the students have excellent $(20 \%)$ or very good $(40 \%)$ respiratory health condition, and 5\% feel it bad; smoking might be a contributing factor to these unfavorable observations;

- $78 \%$ of the students have excellent $(42 \%)$ or very good $(36 \%)$ circulatory and heart condition, and only $3 \%$ feel them bad; 
Table 3. Students' health and nutrition characteristics.

\begin{tabular}{|c|c|c|}
\hline Serial & Characteristics & $\begin{array}{l}\text { Distribu- } \\
\text { tion (100 } \\
\text { Students) }\end{array}$ \\
\hline \multirow[t]{5}{*}{1} & Students' Smoking Habit: & \\
\hline & Non-smokers & 58 \\
\hline & Smoking cigarettes & 23 \\
\hline & Smoking shishah & 14 \\
\hline & Smoking cigarettes and shishah & 5 \\
\hline \multirow[t]{6}{*}{2} & Students' Smoking Index: & \\
\hline & 0 & 58 \\
\hline & $\leq 5$ & 14 \\
\hline & 6 to 15 & 17 \\
\hline & 16 to 25 & 2 \\
\hline & $26+$ & 9 \\
\hline \multirow[t]{6}{*}{3} & Analysis and Evaluation of Students' Week Diet: & \\
\hline & Balanced diet & 36 \\
\hline & Deficient in calories & 9 \\
\hline & Deficient in protein & 16 \\
\hline & Deficient in vitamins and minerals & 21 \\
\hline & Unbalanced diet (lacking many elements) & 18 \\
\hline \multirow[t]{5}{*}{4} & Students' Breakfast at Home: & \\
\hline & Always & 11 \\
\hline & Often & 22 \\
\hline & Sometimes & 51 \\
\hline & Never & 16 \\
\hline \multirow[t]{5}{*}{5} & Students' Breakfast at University: & \\
\hline & Always & 19 \\
\hline & Often & 36 \\
\hline & Sometimes & 40 \\
\hline & Never & 5 \\
\hline \multirow[t]{5}{*}{ 6- } & Students' Dinner at Home: & \\
\hline & Always & 27 \\
\hline & Often & 49 \\
\hline & Sometimes & 23 \\
\hline & Never & 1 \\
\hline \multirow[t]{5}{*}{7} & Students' Supper at Home: & \\
\hline & Always & 19 \\
\hline & Often & 39 \\
\hline & Sometimes & 40 \\
\hline & Never & 2 \\
\hline \multirow[t]{5}{*}{8} & Having Meals Away from Home: & \\
\hline & Always & 7 \\
\hline & Often & 36 \\
\hline & Sometimes & 56 \\
\hline & Never & 1 \\
\hline
\end{tabular}


Table 3. Contd.

\begin{tabular}{|c|c|c|}
\hline Serial & Characteristics & $\begin{array}{l}\text { Distribu- } \\
\text { tion (100 } \\
\text { Students) }\end{array}$ \\
\hline \multirow[t]{4}{*}{9} & Evaluation of Students' Favorite Foods: & \\
\hline & Healthy & 23 \\
\hline & Healthy to some extent & 33 \\
\hline & Unhealthy & 44 \\
\hline \multirow[t]{5}{*}{10} & $\begin{array}{l}\text { Evaluation of Health Condition of Students' Respiratory } \\
\text { System: }\end{array}$ & \\
\hline & Excellent & 20 \\
\hline & Very good & 40 \\
\hline & Good & 35 \\
\hline & $\mathrm{Bad}$ & 5 \\
\hline \multirow[t]{5}{*}{11} & $\begin{array}{l}\text { Evaluation of Health Condition of Students' Circulatory System } \\
\text { and Heart: }\end{array}$ & \\
\hline & Excellent & 42 \\
\hline & Very good & 36 \\
\hline & Good & 19 \\
\hline & $\mathrm{Bad}$ & 3 \\
\hline \multirow[t]{5}{*}{12} & Evaluation of Health Condition of Students' Digestive System: & \\
\hline & Excellent & 28 \\
\hline & Very good & 50 \\
\hline & Good & 16 \\
\hline & $\mathrm{Bad}$ & 6 \\
\hline \multirow[t]{5}{*}{13} & Evaluation of Health Condition of Students' Nervous System: & \\
\hline & Excellent & 31 \\
\hline & Very good & 30 \\
\hline & Good & 32 \\
\hline & $\mathrm{Bad}$ & 7 \\
\hline \multirow[t]{5}{*}{14} & Evaluation of Health Condition of Students' Skin: & \\
\hline & Excellent & 54 \\
\hline & Very good & 29 \\
\hline & Good & 10 \\
\hline & $\mathrm{Bad}$ & 7 \\
\hline
\end{tabular}

- Similarly, $78 \%$ of the students have excellent (28\%) or very good (50\%) digestive system, and 6\% feel it bad;

- $61 \%$ of the students have excellent $(31 \%)$ or very good $(30 \%)$ nervous system, and 7\% feel it bad; and

- $83 \%$ of the students have excellent $(54 \%)$ or very good $(29 \%)$ skin health condition, and $7 \%$ have it bad. 


\subsection{Evaluation of the Students' Intelligence Test}

The evaluation of the result of the intelligence test performed by the students is shown in Table 4 . Only 13\% of the students have been rated as highly intelligent, while mostly one half of them (49\%) have been rated as of average intelligence, and $38 \%$ as having less than average intelligence.

Table 4. Students' intelligence test.

\begin{tabular}{|c|l|c|}
\hline Serial & \multicolumn{1}{|c|}{ Characteristics } & $\begin{array}{c}\text { Distribution } \\
\text { (100 Students) }\end{array}$ \\
\hline $\mathbf{1}$ & Evaluation of Intelligence: & \\
\hline & High & 13 \\
\hline & Average & 49 \\
\hline & Less than average & 38 \\
\hline
\end{tabular}

\subsection{Evaluation of the Students' Physical Fitness Test}

The components of the students' physical fitness test and their final score (from 100) are presented in Table 5. Fifty seven percent of the students' statures are between $171 \mathrm{~cm}$ and $175 \mathrm{~cm}$, while $23 \%$ of them are between $166 \mathrm{~cm}$ and $170 \mathrm{~cm}, 17 \%$ taller than $176 \mathrm{~cm}$, and only $3 \%$ are between $160 \mathrm{~cm}$ and $165 \mathrm{~cm}$. Similar picture is observed with the students' shoulder width, since $46 \%$ of them have it between $41 \mathrm{~cm}$ and $45 \mathrm{~cm}, 29 \%$ between $36 \mathrm{~cm}$ and $40 \mathrm{~cm}, 12 \%$ more than $46 \mathrm{~cm}$, and only $13 \%$ less than $35 \mathrm{~cm}$. Meanwhile, $39 \%$ of the students weights are between $65 \mathrm{~kg}$ and $75 \mathrm{~kg}, 48 \%$ between $76 \mathrm{~kg}$ and $85 \mathrm{~kg}$, and only $13 \%$ heavier than $86 \mathrm{~kg}$; and their skin-fold ranged between $16 \mathrm{~mm}$ and 20 $\mathrm{mm}$ in $87 \%$ of them, between $10 \mathrm{~mm}$ and $15 \mathrm{~mm}$ in $15 \%$, and more than $21 \mathrm{~mm}$ in only $7 \%$ of them. These observations are a natural reflection to the favorable socio-economic and health and nutritional characteristics of the examined students. Also, $71 \%$ have systolic blood pressure between 65 and $75 \mathrm{~mm} \mathrm{Hg}, 24 \%$ between 76 and $85 \mathrm{~mm} \mathrm{Hg}$, and only 5\% higher than $86 \mathrm{~mm} \mathrm{Hg}$; while $61 \%$ of the students have their diastolic blood pressure between 110 and $125 \mathrm{~mm} \mathrm{Hg}, 31 \%$ between $126 \mathrm{~mm} \mathrm{Hg}$ and $135 \mathrm{~mm} \mathrm{Hg}$, and only 8\% higher than $136 \mathrm{~mm} \mathrm{Hg}$. Meantime, their blood cholesterol is less than $5 \mathrm{mmol} / \mathrm{l}$ in $88 \%$ of them, these figures are natural reflections to the students' age distribution. 
Table 5. Students' physical fitness test.

\begin{tabular}{|c|c|c|}
\hline Serial & Characteristics & $\begin{array}{c}\text { Distribution } \\
\text { (100 Students) }\end{array}$ \\
\hline \multirow[t]{5}{*}{1} & Stature $(\mathrm{cm}):$ & \\
\hline & $160-165$ & 3 \\
\hline & $166-170$ & 23 \\
\hline & $171-175$ & 57 \\
\hline & $176+$ & 17 \\
\hline \multirow[t]{6}{*}{2} & Shoulder Width $(\mathrm{cm}):$ & \\
\hline & $25-30$ & 2 \\
\hline & $31-35$ & 11 \\
\hline & $36-40$ & 29 \\
\hline & $41-45$ & 46 \\
\hline & $46+$ & 12 \\
\hline \multirow[t]{8}{*}{3} & Weight (kg): & \\
\hline & $65-70$ & 14 \\
\hline & $71-75$ & 25 \\
\hline & $76-80$ & 33 \\
\hline & $81-85$ & 15 \\
\hline & $86-90$ & 8 \\
\hline & $91-95$ & 3 \\
\hline & $96+$ & 2 \\
\hline \multirow[t]{4}{*}{4} & Skin-Fold (mm): & \\
\hline & $10-15$ & 15 \\
\hline & $16-20$ & 78 \\
\hline & $21+$ & 7 \\
\hline \multirow[t]{7}{*}{5} & Systolic Blood Pressure (mm Hg): & \\
\hline & $110-115$ & 11 \\
\hline & $116-120$ & 12 \\
\hline & $121-125$ & 38 \\
\hline & $126-130$ & 20 \\
\hline & $131-135$ & 11 \\
\hline & $136+$ & 8 \\
\hline \multirow[t]{6}{*}{6} & Diastolic Blood Pressure (mm Hg): & \\
\hline & $65-70$ & 19 \\
\hline & $71-75$ & 52 \\
\hline & $76-80$ & 14 \\
\hline & $81-85$ & 10 \\
\hline & $86+$ & 12 \\
\hline \multirow[t]{6}{*}{7} & Blood Cholesterol (mmo1/1): & \\
\hline & $3.00-3.50$ & 16 \\
\hline & $3.51-4.00$ & 19 \\
\hline & $4.01-4.50$ & 34 \\
\hline & $4.51-5.00$ & 19 \\
\hline & $5.01-5.50$ & 12 \\
\hline \multirow[t]{7}{*}{8} & Peak Flow (1/min): & \\
\hline & $300-350$ & 11 \\
\hline & $351-400$ & 17 \\
\hline & $401-450$ & 6 \\
\hline & $451-500$ & 52 \\
\hline & $501-550$ & 9 \\
\hline & $551-600$ & 5 \\
\hline
\end{tabular}

$(51+: 52,54,54,55,55,55,56)$. 
Table 5. Contd.

\begin{tabular}{|c|c|c|}
\hline Serial & Characteristics & $\begin{array}{l}\text { Distribution } \\
\text { (100 Students) }\end{array}$ \\
\hline \multirow[t]{7}{*}{9} & Grip-Strength (kg): & \\
\hline & $35-40$ & 5 \\
\hline & $41-45$ & 14 \\
\hline & $46-50$ & 35 \\
\hline & $51-55$ & 25 \\
\hline & $56-60$ & 15 \\
\hline & $61+$ & 6 \\
\hline \multirow[t]{6}{*}{10} & Sit and Reach $(\mathrm{cm})$ : & \\
\hline & $20-25$ & 4 \\
\hline & $26-30$ & 23 \\
\hline & $31-35$ & 62 \\
\hline & $36-40$ & 8 \\
\hline & $41+$ & 3 \\
\hline \multirow[t]{5}{*}{11} & Vertical Jump (cm): & \\
\hline & $25-30$ & 11 \\
\hline & $31-35$ & 60 \\
\hline & $36-40$ & 22 \\
\hline & $41+$ & 7 \\
\hline \multirow[t]{6}{*}{12} & Shoulder Flexibility $(\mathrm{cm})$ : & \\
\hline & $120-125$ & 5 \\
\hline & $126-130$ & 20 \\
\hline & $131-135$ & 36 \\
\hline & $136-140$ & 28 \\
\hline & $141+$ & 11 \\
\hline \multirow[t]{6}{*}{13} & Bicycle Ergo-meter (oxygen consumption: $\mathrm{ml} \mathrm{kg/min):}$ & \\
\hline & $20-25$ & 2 \\
\hline & $26-30$ & 27 \\
\hline & $31-35$ & 51 \\
\hline & $36-40$ & 14 \\
\hline & $41+$ & 6 \\
\hline \multirow[t]{6}{*}{14} & Hand \& Eye Coordination (sec): & \\
\hline & $20-25$ & 4 \\
\hline & $26-30$ & 32 \\
\hline & $31-35$ & 39 \\
\hline & $36-40$ & 15 \\
\hline & $41+$ & 10 \\
\hline \multirow[t]{8}{*}{15} & $\begin{array}{l}\text { Evaluation of Student's Physical Fitness (total score out of } \\
\text { 100): }\end{array}$ & \\
\hline & $\leq 25$ & 13 \\
\hline & $26-30$ & 16 \\
\hline & $31-35$ & 20 \\
\hline & $36-40$ & 18 \\
\hline & $41-45$ & 14 \\
\hline & $46-50$ & 12 \\
\hline & $51+$ & 7 \\
\hline
\end{tabular}

$(51+: 52,54,54,55,55,55,56)$. 
However, the students' peak flow is less than 400 liter/min in $28 \%$ of them, between 400 and 500 liter/min in $58 \%$, and higher than 500 liter/min in only $14 \%$ of them. Also, their grip-strength is less than $50 \mathrm{~kg}$ in $54 \%$ of them, and more than $60 \mathrm{~kg}$ in only $6 \%$. Besides, their sit-andreach test revealed that $62 \%$ can achieve reaches between $31 \mathrm{~cm}$ and 35 $\mathrm{cm}$ and only $11 \%$ can reach more than $35 \mathrm{~cm}$, while $27 \%$ of them can reach levels of only $30 \mathrm{~cm}$ and less. Also, their vertical jump ranges between $31 \mathrm{~cm}$ and $35 \mathrm{~cm}$ in $60 \%$ of them, between $36 \mathrm{~cm}$ and $40 \mathrm{~cm}$ in $22 \%$, and higher than this level in only $7 \%$ of them. Their shoulder flexibility, also, ranges between $131 \mathrm{~cm}$ and $140 \mathrm{~cm}$ in $64 \%$ of them, lower than that in $25 \%$, and higher than $140 \mathrm{~cm}$ in only $11 \%$. Moreover, their performance on the bicycle ergo-meter indicated that more than one half of them (51\%) can achieve $31-35 \mathrm{ml} . \mathrm{kg} / \mathrm{min}$, while only $20 \%$ achieve higher levels, while $29 \%$ of them perform lower levels (20-30 $\mathrm{ml} . \mathrm{kg} / \mathrm{min}$ ). All these results are indicative of the relatively low physical fitness of the examined students, most likely due to the lack of practice of physical training and sports. Furthermore, their hand-and-eye coordination test indicated that only $4 \%$ of them achieve this coordination in 20-25 seconds, and 25\% achieve it at periods longer than 35 seconds, and $71 \%$ between these periods (i.e. 26-35 seconds).

As a consequence to that, the assessed total scores of the physical fitness indicate relatively poor students' physical fitness, since only $7 \%$ of them have score more than 50 (out of 100), while $29 \%$ have scores lower than $30,38 \%$ have scores between 31 and 40 , and $26 \%$ have scores between 41 and 50 .

\subsection{Evaluation of the Impact of the Investigated Students' Characteristics and Variables on their Academic Achievement}

The regression equations of all the investigated students' characteristics and variables with their GPAs have been assessed, using ANOVA table. The investigated variables were listed in a descending order of their regression coefficients and the top twenty variables having correlation coefficients $\{\mathrm{R}\}$ exceeding 0.5 and their level of significance less than or equal to 0.05 are presented in Table 6. Meanwhile, further analyses have also been conducted for the variables showing correlation of $0.4,0.5,0.6$ and 0.7 (or more) and the results of these analyses are summarized in Table 7. 
Table 6. List of the twenty investigated* students' variables having correlation coefficient $(R)$ exceeding 0.50 in a descending order of their regression coefficient.

\begin{tabular}{|c|l|c|c|c|}
\hline Serial & \multicolumn{1}{|c|}{ Factor } & $\begin{array}{c}\text { Factor } \\
\text { coefficient }\end{array}$ & R & P \\
\hline 1 & Evaluation of intelligence & 0.30310 & 0.927 & 0.000 \\
\hline 2 & Dependence on University monthly allowance & 0.26633 & 0.918 & 0.000 \\
\hline 3 & Student's memorization of Quran & 0.21330 & 0.889 & 0.001 \\
\hline 4 & $\begin{array}{l}\text { Researcher's evaluation of student's level in english } \\
\text { language }\end{array}$ & 0.19957 & 0.865 & 0.002 \\
\hline 5 & Average of daily study hours & 0.17050 & 0.802 & 0.007 \\
\hline 6 & Dinner at home & 0.16770 & 0.794 & 0.007 \\
\hline 7 & Breakfast at home & 0.15099 & 0.788 & 0.008 \\
\hline 8 & Working and studying together & 0.14678 & 0.761 & 0.009 \\
\hline 9 & Studying pressure (assignments, tests, others) & 0.14570 & 0.669 & 0.022 \\
\hline 10 & Breakfast at University & 0.13863 & 0.661 & 0.022 \\
\hline 11 & $\begin{array}{l}\text { External factors (e.g. being busy with local and } \\
\text { national events) }\end{array}$ & 0.13620 & 0.644 & 0.023 \\
\hline 12 & Level of mother's education & 0.13580 & 0.631 & 0.025 \\
\hline 13 & Living status & 0.12660 & 0.614 & 0.032 \\
\hline 14 & Evaluation of family relations & 0.12224 & 0.611 & 0.033 \\
\hline 15 & Having meals away from home & 0.12090 & 0.609 & 0.034 \\
\hline 16 & Evaluation of student's level in computer application & 0.11510 & 0.602 & 0.036 \\
\hline 17 & Students' opinion about number of courses & 0.11490 & 0.581 & 0.038 \\
\hline 18 & Student's liking of instructors & 0.10410 & 0.544 & 0.041 \\
\hline 19 & Marriage & 0.10378 & 0.529 & 0.046 \\
\hline 20 & Number of students in class room & 0.10285 & 0.513 & 0.050 \\
\hline
\end{tabular}

* The total investigated variable $=57$

Table 7. Summary of the analyses of variables showing different correlations with students' GPA.

\begin{tabular}{|c|c|c|}
\hline Correlation coefficient & Number of variables & Residual error \\
\hline 0.4 & 22 & 0.194 \\
\hline 0.5 & 20 & 0.182 \\
\hline 0.6 & 16 & 0.196 \\
\hline 0.7 & 8 & 0.217 \\
\hline
\end{tabular}

Consequently, the top twenty variables have been selected for further analyses, since the residual error is the lowest. The regression equations for these variables with the students' GPAs have been assessed, using the same above-studied technique ANOVA table. Also, the significances of the relations of the highlighted 20 variables on the students' GPAs were further tested using t-test, and the results of the analysis are presented in Table 8 . The students who are single and living with their families $(n=52)$ have the highest GPA which is significantly different from their single colleagues who are living alone $(n=17)$ 
( $p<0.001$ ), indicating the importance of the students living stability on their academic achievement. This conclusion is further supported by the fact that the students who enjoy high and/or even normal family relation have significantly higher GPA than their colleagues who suffer from low family relation $(\mathrm{p}<001)$. Also, the students whose mothers are illiterate have significantly lower GPAs than their colleagues whose mothers are highly educated, $(p<0.05)$ (university graduates and/or postgraduates). Meanwhile, the students who are not receiving university allowances $(n=8)$ have the lowest GPAs, followed by those who are in need of the allowance and use it in everyday living expenses, the differences are significant from the other well-to-do colleagues who use the allowance in recreation purpose and/or using it in educational requisites $(\mathrm{p}<0.001)$. These results indicate the importance of the students economic status on their academic achievement. This conclusion is further supported by the fact that the students who need to work in order to support their living $(n=15)$ have significantly lower GPA than their colleagues who are only studying $(\mathrm{p}<0.05)$. However, the fact that the students who are not getting allowances spent more than five years in college (i.e. have bad achievement likely due to personal reasons, e.g. level of intelligence) might bias, to some extent, the above stated conclusion.

As related to the impact of students' background in the English language, the computer applications and the memorizing of Quran, all of them significantly affect students GPAs. For example, the students who have weak background in English language have significantly lower GPAs $(\mathrm{p}<0.01)$ than the rest of their colleagues; also, those who are weak in computer applications have significantly lower GPAs $(\mathrm{p}<0.05)$ than the colleagues with intermediate and excellent computer experience; moreover, the students who memorize all or part of the Quran have significantly higher GPAs $(p<0.5-0.01)$ than their colleagues who only, or rarely, read Quran. This finding may be strongly supported by AlAmir report (2007) ${ }^{[38]}$, who reviewed studies conducted in KSA and Qatar on the impact of memorizing Quran on the academic achievement of the students. Such relation has been subjected to investigation in the past two decades since 1991 (three studies in KSA), one study in Qatar (1994), and all the studies reported positive relation between memorizing Quran and the scholastic achievements of the students in primary schools ( ${ }^{\text {th }}$ to $6^{\text {th }}$ grades). Furthermore, the Ministry of Education in KSA (General Directorate of Educational Research) carried out a comparative 
study of the scores of the graduates of both the general education schools and the Quran memorizing schools in 2003 in 12 directorates of education in the kingdom ${ }^{[39]}$. The findings of the study concluded that the scores of Quran memorizing schools' students were always higher than those of the general education schools. These findings have been attributed by many authors to some or all of the following reasons ${ }^{[38-42]}$.

1- Developing of the habit of listening and concentration among the Quran candidates, who oftenly begin memorizing Quran at early ages.

2- Progressing candidates memorizing capability, particularly at their early ages, and, consequently, improving their academic achievement.

3- Controlling candidates' behavior, and stabilising their personalities, thus forming optimal citizens dedicated to their studies and achieving high scholatic scores.

Out of the six variables (within the selected 20 variables of utmost effect on students' academic achievement) which are related to the educational and study operations in and out of college, including: (a) number of courses, (b) students' daily study hours, (c) students' involvements or interests in out-of-college-events, (d) study burden, (e) number of students in the classroom, and (f) students' relation with their instructors, the first three variables show significant differences within the students subgroups $(\mathrm{p}<0.05-0.001)$. For example, the students who register for many courses have significantly lower GPAs than their colleagues who register for a fair number of courses; also, the students who study for 3 hours (or more) daily have significantly higher GPAs than those who study for two hours or less $(p<0.05-0.001)$; and the students who are involved and/or interested in out-of-college activities have significantly higher GPAs $(\mathrm{p}<0.05)$ than their colleagues who are not involved in such activities.

Meanwhile, the students' dietary habits have a significant impact on their academic achievements. The students who always get their breakfast and dinner at home have significantly higher GPAs than their colleagues who never get them, or get them sometimes, at home $(p<0.05$ $0.01)$. On the other hand, the students who always get their breakfast at the university or get their meals away from home have significantly 
lower GPAs than their colleagues who have different dietary habits $(p<0.05-0.01)$. These findings may be further supported by the above mentioned previous studies and reports ${ }^{[1,2,12,25,26]}$.

Table 8. Results of the t-test for measuring the significance of the levels of the selected variables' impact on student's GPA.

\begin{tabular}{|c|c|c|c|c|c|}
\hline Serial & Variables Levels & $\mathbf{N}$ & $\mathbf{M} \pm \mathbf{S} . \mathbf{D}$ & $\begin{array}{c}\text { t-test (P- } \\
\text { value) }\end{array}$ & $\begin{array}{c}\text { Level of } \\
\text { Significant } \\
(\mathrm{P}<0.05)\end{array}$ \\
\hline 1- & Living Status: & & & & \\
\hline $\mathbf{a}$ & Single and living alone & 17 & $2.96 \pm 0.38$ & \multirow{4}{*}{$\begin{array}{c}\mathrm{a} \& \mathrm{~b}=0.15 \\
\mathrm{a} \& \mathrm{c}=0.00 \\
\mathrm{c} \& \mathrm{~d}=0.08 \\
\text { all others } \\
\mathrm{P}>0.05\end{array}$} & \multirow{4}{*}{$\begin{array}{l}\text { There is a significant } \\
\text { difference only } \\
\text { between a \& c } \\
(\mathrm{P}<0.001) \text {. }\end{array}$} \\
\hline $\mathbf{b}$ & Single and living with colleagues & 13 & $3.30 \pm 0.73$ & & \\
\hline c & Single and living with family & 52 & $3.49 \pm 0.69$ & & \\
\hline d & $\begin{array}{l}\text { Married and living with his wife \& } \\
\text { children only }\end{array}$ & 18 & $3.13 \pm 0.75$ & & \\
\hline 2- & Marital Status: & & & & \\
\hline $\mathbf{a}$ & Married & 18 & $2.91 \pm 0.65$ & \multirow{2}{*}{$\mathrm{a} \& \mathrm{~b}=0.033$} & \multirow{2}{*}{$\begin{array}{l}\text { There is a significant } \\
\text { difference between } \\
\mathrm{a} \& \mathrm{~b}(\mathrm{P}<0.05) \text {. }\end{array}$} \\
\hline b & Not Married & 82 & $3.35 \pm 0.75$ & & \\
\hline 3- & $\begin{array}{l}\text { Dependence on University Monthly } \\
\text { Allowance: }\end{array}$ & & & & \\
\hline $\mathbf{a}$ & Used in recreation purposes only & 19 & $3.57 \pm 0.59$ & \multirow{4}{*}{$\begin{array}{c}\mathrm{a} \& \mathrm{~b}>0.15 \\
\mathrm{a} \& \mathrm{c}=0.006 \\
\mathrm{a} \& \mathrm{~d}=0.00 \\
\mathrm{~b} \& \mathrm{c}=0.002 \\
\mathrm{~b} \& \mathrm{~d}=0.00 \\
\mathrm{c} \& \mathrm{~d}=0.004\end{array}$} & \multirow{4}{*}{$\begin{array}{l}\text { There are highly } \\
\text { significant differences } \\
\text { between a \& c, a \& d, } \\
\text { b \& c, b \& d and c \& } \\
\text { d ( } \mathrm{P}<0.01-0.001 \text { ) (but } \\
\text { not for a \& b only). }\end{array}$} \\
\hline $\mathbf{b}$ & Used in educational requisites only & 34 & $3.59 \pm 0.71$ & & \\
\hline c & $\begin{array}{l}\text { Used in educational requisites \& } \\
\text { living purposes }\end{array}$ & 39 & $3.09 \pm 0.58$ & & \\
\hline d & No allowances & 8 & $2.55 \pm 0.37$ & & \\
\hline 4- & Level of Mother's Education & & & & \\
\hline $\mathbf{a}$ & Postgraduate & 5 & $3.41 \pm 0.28$ & \multirow{6}{*}{$\begin{array}{c}\mathrm{a} \& \mathrm{e}=0.03 \\
\mathrm{a} \& \mathrm{f}=0.02 \\
\text { all others } \\
\mathrm{P}>0.05\end{array}$} & \multirow{6}{*}{$\begin{array}{l}\text { There are significant } \\
\text { differences between } \\
\text { a \& e, and a \& f } \\
(\mathrm{P}<0.05) \text { only. }\end{array}$} \\
\hline $\mathbf{b}$ & Graduate & 19 & $3.39 \pm 0.39$ & & \\
\hline c & Intermediate & 28 & $3.19 \pm 0.72$ & & \\
\hline d & Fundamental & 32 & $3.41 \pm 0.60$ & & \\
\hline e & Read / write & 6 & $2.96 \pm 0.91$ & & \\
\hline $\mathbf{f}$ & Illiterate & 10 & $3.19 \pm 0.55$ & & \\
\hline 5- & Work of Student Beside Study: & & & & \\
\hline $\mathbf{a}$ & Work and study & 15 & $2.89 \pm 0.64$ & \multirow[b]{2}{*}{$\mathrm{a} \& \mathrm{~b}=0.01$} & \multirow{2}{*}{$\begin{array}{l}\text { There is a highly } \\
\text { significant difference } \\
\text { between a \& b } \\
(\mathrm{P}<0.01) \text {. }\end{array}$} \\
\hline b & Study only & 85 & $3.39 \pm 0.67$ & & \\
\hline 6- & $\begin{array}{l}\text { Student's Level in Practicing } \\
\text { English: }\end{array}$ & & & & \\
\hline $\mathbf{a}$ & Excellent & 27 & $3.55 \pm 0.66$ & \multirow{4}{*}{$\begin{array}{c}\mathrm{a} \& \mathrm{~b}=0.005 \\
\mathrm{a} \& \mathrm{c}=0.008 \\
\mathrm{a} \& \mathrm{~d}=0.00 \\
\text { all others } \\
\mathrm{P}>0.05\end{array}$} & \multirow{4}{*}{$\begin{array}{l}\text { There are highly } \\
\text { significant } \\
\text { differences between } \\
\text { a \& b, a \& c and } \\
\text { a \& d }(\mathrm{P}<0.01) \text {. }\end{array}$} \\
\hline b & Good & 21 & $3.36 \pm 0.64$ & & \\
\hline $\mathbf{c}$ & Fair & 32 & $3.36 \pm 0.74$ & & \\
\hline d & Weak & 20 & $2.86 \pm 0.50$ & & \\
\hline 7- & $\begin{array}{l}\text { Student's Level in Computer } \\
\text { Applications: }\end{array}$ & & & & \\
\hline $\mathbf{a}$ & Excellent & 25 & $3.41 \pm 0.66$ & \multirow{4}{*}{$\begin{array}{c}\mathrm{a} \& \mathrm{c}=0.044 \\
\mathrm{a} \& \mathrm{~d}=0.025 \\
\text { all others } \\
\mathrm{P}>0.05\end{array}$} & \multirow{4}{*}{$\begin{array}{l}\text { There are significant } \\
\text { differences between } \\
\text { a \& c and a \& d } \\
(\mathrm{P}<0.05) \text {. }\end{array}$} \\
\hline b & Good & 36 & $3.45 \pm 0.68$ & & \\
\hline c & Fair & 25 & $3.19 \pm 0.70$ & & \\
\hline d & Weak & 14 & $2.99 \pm 0.69$ & & \\
\hline 8- & Student's Liking of Instructors: & & & & \\
\hline $\mathbf{a}$ & Student likes a few instructors & 27 & $2.87 \pm 0.73$ & \multirow{4}{*}{$\begin{array}{c}\mathrm{a} \& \mathrm{~b}=0.02 \\
\mathrm{a} \& \mathrm{c}=0.01 \\
\mathrm{a} \& \mathrm{~d}=0.03 \\
\text { all others } \\
\mathrm{P}>0.05\end{array}$} & \multirow{4}{*}{$\begin{array}{l}\text { There are significant } \\
\text { differences between } \\
\text { a \& b and a \& d } \\
(\mathrm{P}<0.05) \text { and a \& c } \\
(\mathrm{P}<0.01) \text {. }\end{array}$} \\
\hline $\mathbf{b}$ & Student likes some instructors & 42 & $3.39 \pm 0.67$ & & \\
\hline c & Student likes most instructors & 25 & $3.45 \pm 0.68$ & & \\
\hline d & Student likes all instructors & 6 & $3.33 \pm 0.67$ & & \\
\hline
\end{tabular}


Table 8. Contd.

\begin{tabular}{|c|c|c|c|c|c|}
\hline Serial & Variables Levels & $\mathbf{N}$ & $\mathbf{M} \pm \mathbf{S} . \mathbf{D}$ & t-test (P-value) & $\begin{array}{c}\text { Level of } \\
\text { Significant } \\
(\mathbf{P}<\mathbf{0 . 0 5})\end{array}$ \\
\hline 9- & Number of Courses: & & & & \\
\hline $\mathbf{a}$ & Great number of courses & 58 & $\begin{array}{c}3.07 \pm \\
0.71\end{array}$ & \multirow{2}{*}{$\mathrm{a} \& \mathrm{~b}=0.03$} & \multirow{2}{*}{$\begin{array}{l}\text { There is significant } \\
\text { difference between } \\
\mathrm{a} \& \mathrm{~b}(\mathrm{P}<0.05) \text {. }\end{array}$} \\
\hline b & Fair number of courses & 42 & $\begin{array}{c}3.45 \pm \\
0.64 \\
\end{array}$ & & \\
\hline 10- & Social Relations with the Family: & & & & \\
\hline a & High & 13 & $\begin{array}{c}3.19 \pm \\
0.43\end{array}$ & \multirow{3}{*}{$\begin{array}{l}\mathrm{a} \& \mathrm{~b}=0.12 \\
\mathrm{a} \& \mathrm{c}=0.00 \\
\mathrm{~b} \& \mathrm{c}=0.00\end{array}$} & \multirow{3}{*}{$\begin{array}{l}\text { There are highly } \\
\text { significant } \\
\text { differences between } \\
\text { a \& c and b \& c } \\
(\mathrm{P}<0.001) \text { but no } \\
\text { significant difference } \\
\text { exists between a \& b } \\
(\mathrm{P}>0.05) \text {. }\end{array}$} \\
\hline b & Normal & $\mathbf{7 0}$ & $\begin{array}{c}3.43 \pm \\
0.71 \\
\end{array}$ & & \\
\hline c & Low & 17 & $\begin{array}{c}2.29 \pm \\
0.61\end{array}$ & & \\
\hline 11- & $\begin{array}{l}\text { Student's Evaluation of his Study } \\
\text { Burden (assignment, tests, others): }\end{array}$ & & & & \\
\hline $\mathbf{a}$ & $\begin{array}{l}\text { Study pressure affects academic } \\
\text { achievement }\end{array}$ & 56 & $\begin{array}{c}3.11 \pm \\
0.41 \\
\end{array}$ & \multirow{2}{*}{$\mathrm{a} \& \mathrm{~b}=0.03$} & \multirow{2}{*}{$\begin{array}{l}\text { There is a } \\
\text { significant } \\
\text { difference } \\
\text { between } \\
\text { a \& b }(\mathrm{P}<0.05) \text {. }\end{array}$} \\
\hline b & $\begin{array}{l}\text { Study pressure doesn't affect } \\
\text { academic achievement }\end{array}$ & 44 & $\begin{array}{c}3.48 \pm \\
0.61 \\
\end{array}$ & & \\
\hline 12- & $\begin{array}{l}\text { Student's Evaluation of Students' } \\
\text { Number in Classroom: }\end{array}$ & & & & \\
\hline $\mathbf{a}$ & Affects academic achievement & 35 & $\begin{array}{c}3.02 \pm \\
0.66\end{array}$ & \multirow[b]{2}{*}{$\mathrm{a} \& \mathrm{~b}=0.04$} & \multirow{2}{*}{$\begin{array}{l}\text { There is a } \\
\text { significant } \\
\text { difference } \\
\text { between } \\
\text { a \& b }(P<0.05) \text {. }\end{array}$} \\
\hline b & Doesn't affect academic achievement & 65 & $\begin{array}{c}3.34 \pm \\
0.78\end{array}$ & & \\
\hline 13- & $\begin{array}{l}\text { Student's Involvements or } \\
\text { Interests in Out-of-College Events } \\
\text { (e.g. being busy with local and } \\
\text { International events): }\end{array}$ & & & & \\
\hline $\mathbf{a}$ & Affects academic achievement & 42 & $\begin{array}{c}3.10 \pm \\
0.19 \\
\end{array}$ & \multirow{2}{*}{$\mathrm{a} \& \mathrm{~b}=0.03$} & \multirow{2}{*}{$\begin{array}{l}\text { There is a } \\
\text { significant } \\
\text { difference } \\
\text { between } \\
\text { a \& b }(\mathrm{P}<0.05) \text {. }\end{array}$} \\
\hline b & Doesn't affect academic achievement & 58 & $\begin{array}{c}3.40 \pm \\
0.40\end{array}$ & & \\
\hline 14- & Average of Daily Study Hours: & & & & \\
\hline $\mathbf{a}$ & Less than one hour & 21 & $\begin{array}{c}2.92 \pm \\
0.55 \\
\end{array}$ & \multirow{4}{*}{$\begin{array}{c}\text { a \& b }=0.09 \\
\text { a \& c }=0.004 \\
\text { a \& d }=0.006 \\
\text { b \& c }=0.04 \\
\text { c \& d }=0.44\end{array}$} & \multirow{4}{*}{$\begin{array}{l}\text { There are } \\
\text { significant } \\
\text { differences } \\
\text { between } \\
\text { a \& c, a \& d } \\
(\mathrm{P}<0.01) \text {, and b \& } \\
\text { c }(\mathrm{P}<0.05) \text {. }\end{array}$} \\
\hline b & One hour to less than three & 33 & $\begin{array}{c}3.04 \pm \\
0.47\end{array}$ & & \\
\hline c & Three to less than Five & 36 & $\begin{array}{c}3.54 \pm \\
0.66 \\
\end{array}$ & & \\
\hline d & Five hours and more & 10 & $\begin{array}{c}3.52 \pm \\
0.74\end{array}$ & & \\
\hline 15- & Student's Memorization of Quran: & & & & \\
\hline $\mathbf{a}$ & Memorizing all Quran & 6 & $\begin{array}{c}3.76 \pm \\
0.83 \\
\end{array}$ & \multirow{4}{*}{$\begin{array}{l}\text { a \& b =0.95 } \\
\text { a \& c }=0.005 \\
\text { a \& d =0.13 } \\
\text { b \& c }=0.002 \\
\text { b \& d =0.13 } \\
\text { c \& d =0.79 }\end{array}$} & \multirow{4}{*}{$\begin{array}{l}\text { There are highly } \\
\text { significant } \\
\text { differences } \\
\text { between a \& c and } \\
\text { b \& c } \\
(\mathrm{P}<0.01) \text {. }\end{array}$} \\
\hline b & Memorizing parts of Quran & 29 & $\begin{array}{c}3.65 \pm \\
0.74 \\
\end{array}$ & & \\
\hline c & Reads Quran only & 49 & $\begin{array}{c}3.11 \pm \\
0.62 \\
\end{array}$ & & \\
\hline d & Rarely reads Quran & 16 & $\begin{array}{c}3.12 \pm \\
0.46\end{array}$ & & \\
\hline
\end{tabular}


Table 8. Contd.

\begin{tabular}{|c|c|c|c|c|c|}
\hline 16- & Breakfast at Home: & & & & \multirow{5}{*}{$\begin{array}{l}\text { There are highly } \\
\text { significant } \\
\text { differences } \\
\text { between a \& d and } \\
\mathrm{c} \& \mathrm{~d}(\mathrm{P}<0.01), \\
\text { and significant } \\
\text { differences } \\
\text { between } \\
\text { a \& b and a \& c } \\
(\mathrm{P}<0.05) \text {. }\end{array}$} \\
\hline $\mathbf{a}$ & Always & 11 & $\begin{array}{c}3.89 \pm \\
0.69 \\
\end{array}$ & \multirow{4}{*}{$\begin{array}{c}\mathrm{a} \& \mathrm{~b}=0.02 \\
\mathrm{a} \& \mathrm{c}=0.02 \\
\mathrm{a} \& \mathrm{~d}=0.004 \\
\mathrm{~b} \& \mathrm{c}=0.35 \\
\mathrm{~b} \& \mathrm{~d}=0.33 \\
\mathrm{c} \& \mathrm{~d}=0.006\end{array}$} & \\
\hline b & Often & 22 & $\begin{array}{c}3.26 \pm \\
0.61\end{array}$ & & \\
\hline c & Sometimes & 51 & $\begin{array}{c}3.27 \pm \\
0.71 \\
\end{array}$ & & \\
\hline d & Never & 16 & $\begin{array}{c}3.09 \pm \\
0.54\end{array}$ & & \\
\hline 17- & Breakfast at University: & & & & \multirow{4}{*}{$\begin{array}{l}\text { There are } \\
\text { significant } \\
\text { differences } \\
\text { between } \\
\text { a \& b }(\mathrm{P}<0.05) \text {, } \\
\text { and } \\
\text { a \& c }(\mathrm{P}<0.01) \text {. }\end{array}$} \\
\hline $\mathbf{a}$ & Always & 19 & $\begin{array}{c}2.99 \pm \\
0.45\end{array}$ & \multirow{3}{*}{$\begin{array}{c}\mathrm{a} \& \mathrm{~b}=0.03 \\
\mathrm{a} \& \mathrm{c}=0.005 \\
\mathrm{~b} \& \mathrm{c}=0.57\end{array}$} & \\
\hline b & Often & 36 & $\begin{array}{c}3.34 \pm \\
0.71 \\
\end{array}$ & & \\
\hline c & Sometimes & 45 & $\begin{array}{c}3.43 \pm \\
0.73\end{array}$ & & \\
\hline 18- & Dinner at Home: & & & & \\
\hline $\mathbf{a}$ & Always & 19 & $\begin{array}{c}3.56 \pm \\
0.77\end{array}$ & \multirow{3}{*}{$\begin{array}{l}a \& b=0.57 \\
a \& c=0.03 \\
b \& c=0.57\end{array}$} & \multirow{3}{*}{$\begin{array}{l}\text { There is a } \\
\text { significant } \\
\text { difference } \\
\text { between } \\
\text { a \& c }(P<0.05) \text {. }\end{array}$} \\
\hline b & Often & 39 & $\begin{array}{c}3.34 \pm \\
0.72 \\
\end{array}$ & & \\
\hline c & Sometimes & 42 & $\begin{array}{c}3.09 \pm \\
0.57\end{array}$ & & \\
\hline 19- & Having Meals away from Home: & & & & \\
\hline $\mathbf{a}$ & Always & 7 & $\begin{array}{c}3.11 \pm \\
0.75\end{array}$ & \multirow{3}{*}{$\begin{array}{l}a \& b=0.27 \\
\text { a \& c }=0.04 \\
b \& c=0.10\end{array}$} & \multirow{3}{*}{$\begin{array}{l}\text { There is a } \\
\text { significant } \\
\text { difference } \\
\text { between } \\
\text { a \& } \mathrm{c}(\mathrm{P}<0.05)\end{array}$} \\
\hline b & Often & 36 & $\begin{array}{c}3.40 \pm \\
0.72 \\
\end{array}$ & & \\
\hline c & Sometimes & 57 & $\begin{array}{c}3.21 \pm \\
0.66\end{array}$ & & \\
\hline 20- & Test of Intelligence: & & & \multirow{4}{*}{$\begin{array}{l}a \& b=0.02 \\
a \& c=0.00 \\
b \& c=0.00\end{array}$} & \\
\hline $\mathbf{a}$ & High intelligence & 13 & $\begin{array}{c}3.95 \pm \\
0.61\end{array}$ & & \multirow{3}{*}{$\begin{array}{l}\text { There are highly } \\
\text { significant } \\
\text { differences } \\
\text { between a \& c and } \\
\mathrm{b} \& \mathrm{c}(\mathrm{P}<0.001) \\
\text { and between a \& b } \\
(\mathrm{P}<0.05) \text {. }\end{array}$} \\
\hline b & Normal intelligence & 49 & $\begin{array}{c}3.42 \pm \\
0.66\end{array}$ & & \\
\hline c & Low intelligence & 38 & $\begin{array}{c}2.95 \pm \\
0.50\end{array}$ & & \\
\hline
\end{tabular}

The last most important variable affecting students' academic achievement, but not the least, is their level of intelligence (as evaluated by the International Society of High IQ Arabic Individuals' Intelligence Test). The students who have been categorized as having low intelligence have significantly lower GPAs than those classified as having high or normal intelligence $(p<0.001)$, while there is no significant difference in the GPAs of the latter two classes.

\section{Conclusions and Recommendations}

It may be concluded from the present study that the main factors which might have impact on the academic achievement of the students of the Colleges of King Abdulaziz University (KAU), as assessed by the 
GPA levels of the sample of Engineering students, can be categorized under three headings: (a) Academic, (b) Economic, (c) Cultural, Social and Health factors. The main academic effective factors include: student's level of intelligence as measured by the test of the high Intelligence Questions (IQ) for the Arabic individuals, the student's background education of the holy Quran, English language and computer practice, where the students who are highly scored in these factors have significantly higher GPAs $(\mathrm{p}<0.05)$ than their colleagues. However, the "relatively exceeding" number of courses attended by students through the academic semester showed negative impact on their GPA; meanwhile, the academic burden of the tests, assignments and other academic requirements has effect on it.

The need of the students for the university stipend represents the main studied economic factor which has impact on their academic achievements. The students who use the stipend for satisfying their basic needs, and those who do not receive any allowances, have significantly lower GPAs $(\mathrm{P}<0.05)$ than their colleagues. Meanwhile, the students who work beside their study, to support their living, have significantly lower GPAs $(\mathrm{P}<0.05)$ than those who study only.

The main effective cultural, social and health factors include: the students' involvements in community scientific, cultural and social events, where such students have significantly higher $(\mathrm{P}<0.05)$ GPAs than the others who do not practice such activities. Meanwhile, those who enjoy "favorable" social relations within their families, as well as those who have highly educated mothers, have significantly higher $(\mathrm{P}<0.05)$ GPAs than their colleagues; the better economic status of the formers might have some impact on that. Besides, the dietary habits of getting breakfast and dinner regularly at home have a good impact on students' health and, consequently, on their academic achievement, where the students who have this practice get significantly higher GPAs $(\mathrm{P}<0.05)$ than the others who do not behave similarly.

However, the above stated factors might have masked the anticipated impact of the students' health fitness on their academic achievement. Consequently, it is recommended to further investigate the subject with widening the scope, and increasing the numbers of the studied students. 
Furthermore, and other than the students' intelligence levels, as well as their socio-economic status, living status, such as housing, transport, and familiar relations, those have significant impacts on student's academic achievement, and are community controlled, it is recommended to carry out interventions in the educational process to improve students achievements. The recommended areas for intervention include:

1. Encouraging students' to improve their background of the English language and of computer applications, as well as, installing facilities in universities for presenting substantiated related educational programs for students.

2. Improving students' study skills through training on optimal studying techniques, encouraging memorizing Quran, and extending their studying hours.

3. Optimizing students' study burden by limiting the number of allowed registered courses to the optimal, and limiting other study burdens, such as home works, quizzes, examinations and projects to the optimal.

4. Encouraging students to improve their dietary habits by relying nearly completely on home feeding and reducing their uptake of fast food to the minimal.

5. Last, but not least, widening the scope of this study to cover students of other colleges in KAU, and of other Saudi universities, both males and feamles.

\section{References}

[1] California School, Helping School boards Enact Policies that Support Healthy Eating: http://www.healthylunches .org/articles.htm, Feb, 2006.

[2] Taras, H., Physical Activity and Student Performance at School, J. School Health, 75: 21418 (2005).

[3] Carlson, J., The Multimodal Effect of Physical Exercise, Elementary School Guidance and Counseling, 16: 304-309 (1982).

[4] Lopez, R. and Pruett, D.M., The Chile Runner, Journal of Physical Education, Recreation, and Dance, 53: 78-81 (1982).

[5] Duncan, B., Boyce, W.T., Itami, R. and Puffenbarger, N., A Controlled Trial of a Physical Fitness Program For Fifth Grade Students, Journal of School Health, 53: 467-471 (1983).

[6] Shipman, W.M., Emotional and Behavioral Effects of Long-Distance Running on Children. In: M.L. Sachs \& G.W. Buffone (Eds.), Running as Therapy (pp: 125-137), Lincoln, University of Nebraska Press (1984). 
[7] Ross, J.G. and Gilbert, G.G., The National Children and Youth Fitness Study: A Summary of Findings. Journal of Physical Education, Recreation, and Dance, 56: 45-50 (1985).

[8] Tuckman, B.W. and Hinkle, J.S., An Experimental Study of The Physical and Psychological Effects of Aerobic Exercise on School Children, J. Health Psychology, 5: 197207 (1986).

[9] Hinkle, J.S. and Tuckman, B.W., Children's Fitness: Managing a Running Program. Journal of Physical of Education, Recreation, and Dance, 58: 58-61 (1987).

[10] Hinkle, J.S., Psychological Benefits of Aerobic Running: Implications for Mental Health Counselors. Journal of Mental Health Counseling, 10: 253-261 (1988).

[11] Blackwell, E.D., Jr., Physical Fitness is a Central Curriculum Issue, Journal of Physical Education, Recreation, and Dance, 61: 18 (1990).

[12] Patrick, K., Spear, B. and Holt, K. and Sofka, D. (Eds.), Bright Futures in Practice: Physical Activity. National Center for Education in Maternal and Child Health, Georgetown University, Arlington, VA (2001).

[13] Caprara, G.V., Barbaranelli, C., Postorelli, C., Bandura, A. and Zimbardos, P.G., Prosocial Foundations of Children's Academia Achievement, J. Psychological Science, 11: 302-6 (2000).

[14] Chen, X., Chang, L. and He, Y., The Peer Group as a Context: Mediating and Moderating Effects on Relations between Academic Achievement and Social Functioning in Chinese Children, Children Development, 74: 710 (2003).

[15] Chambel, M.J. and Curra, L., Stress in Academic Life: Work Characteristics as Predictors of Students Well-being and Performance, Applied Psychology: An International Review, 54: 135 (2005).

[16] Marsh, H.W., Trawtwein, U., Ludtke, O., Koller, O. and Baumert, J., Integration of Multidimensional Self-Concept and Core Personality Constructs: Construct Validation and Relations to Well-Being and Achievement, J. Personality, 74: 403 (2006).

[17] Coleman, James S., Equality of Educational Opportunity (COLEMAN) STUDY (EEOS) (1966) [Computer file]. 2nd ICPSR version. Washington, DC: U.S. Department of Health, Education, and Welfare, Office of Education/National Center for Education Statistics [producer] (1999) Ann Arbor, MI: Inter-university Consortium for Political and Social Research [distributor] (2000).

[18] Kekelis, L. and Sacks, S., The effects of Visual Impairment on Children's Social Interactions in Regular Education Programs. In: S. Sacks, L. Kekelis and R. Gaylord-Ross (Eds.), The Development of Social Skills by Blind and Visually Impaired Students, New York: American Foundation for the Blind (1992).

[19] Rogow, The Psychosocial Experiences of a Student with Low Vision, Journal of Visual Impairment and Blindness, 93 (1999).

[20] McGaha, Farran, Enhancing The Social Interaction Skills of Preschoolers with Visual Impairments, Journal of Visual Impairment and Blindness, 95 (2001).

[21] Corn and Bishop, V.E., Acquisition of Practical Knowledge by Blind and Visually Impaired Students in Grades 8-12, Journal of Visual Impairment and Blindness, 78: 352-356 (1984).

[22] Physical-Fitness; Exercise; Health; Theory, (1988): http://secure.sportquest.com/su2.cfm? articleno $=230475 \&$ title $=230475$, April, 2011 (visit date).

[23] http://www.cdc.gov/physicalactivity/everyone/glossary/index.html, Aprill, 2011 (visit date).

[24] Greenberg, J., Dintiman, G. and Oakes, B., Physical Fitness and Wellness, Pearson Education, Inc. USA (2004).

[25] Robert, P. Pangrazi and Charles, B. Corbin, Factors that Influence Physical Fitness in Children and Adolescents, The Cooper Institute for Aerobics Research (1992).

[26] http://www.oberlin.edu/faculty/ndarling/adbio2.htm, Feb, 2006 (visit date).

[27] http://www.nature.com/oby/indexhtml, April, 2011 (visit date).

[28] Dishman, R.K. and Sallis, J.F., Determinants and Interventions for Physical Activity and Exercise. In: C. Bouchard, R.J. Shephard and T. Stephens (Eds.), Physical Activity, Fitness, 
and Health: International Proceedings and Consensus Statement (pp: 214-238) Champaign, IL: Human Kinetics Publishers (1994).

[29] Sallis, James F., Influences on Physical Activity of Children, Adolescents, and Adults. San Diego State University, Pub., 1: 7 (2000).

[30] http://www.cdc.gov/nccdphp/dnpa/physical/terms/index.htm, April, 2011 (visit date).

[31] Benefit of Physical Activity and Exercise on Body: http://www.faqs.org/health/HealthyLiving-V1/Physical-Fitness.htm1, April, 2011 (visit date).

[32] Physical Activity in Children and Adolescents: http://www.brightfutures.org/physicalactivity/intro/006_011.html April, 2011 (visit date).

[33] Walter, M. Ensel and Nan Lin, Physical Fitness and the Stress Process, Journal of Community Psychology, 32(1): 81-101, Wiley Periodicals, Inc. (2004).

[34] Valerie, J. Easton and John, H. McColl's, Statistics Glossary, vol. 1: http://www.stat.yale.edu/Courses/1997-98/101/sample.htm, March, 2006 (visit date).

[35] International Society of High Intelligence Questions Arabic Individuals: http:www.arabicnation.com/cgi-bin/quirex2/index.cgi?quiz=iq1, April, 2006 (visit date).

[36] Lafayette, Physical Fitness Kit Operation Manual. Lafayette Co. Indiana (47903), USA (1990).

[37] Ronald, E.W., Raymond, H.M and Sharon, L.M., Probability and Statistics for Engineering and Scientists, Prentice Hall, Inc. New Jersey, USA (1998).

[38] Al-Amir, A.O., http://majdu.gov.sa (2007), (In Arabic), March, 2011 (visit date).

[39] General Directorate of Education Research, A Comparative Study of the Scholastic Achievements of the General Education Schools Graduates and the Quran Memorizing Schools Graduates. Ministry of Education, KSA, (1423H) (2002) (In Arabic).

[40] Yusuf, M.A., Proceeding of Quran on Community Development, Cairo, Dar El-salam (2000) (In Arabic).

[41] Abdullatif, E.A., The Impact of Memorizing Quran on Scholastic Achievement and Personal Behavior (Msc Thesis), Dar Konoz Ashbelia (2010) (In Arabic).

[42] Quran Memorizing Society, Editorial: Mawakib Journal, No.27 (1426H) (2006) p.9, Jeddah (In Arabic). 
دراسة التحصيل العلمي لطلاب كلية الهندسة بجامعة الملك عبدالعزبز وعلاقته بلياقتهم البدنية وسلامتهم النفسية

عبدالله عمر بافيل، و مدبولي حامد نوير، و إبراهيم محمد جمعة، و عبدالرحمن محمد باسهل

قسم الهندسة الصناعية، كلية العندسة، جامعة العلك عبدالعزيز،

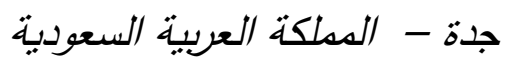

الستنظص. أجريت الدراسة على عينة عشوائية منطابقة لمائة طالب من كلية الهندسة بجامعة الملك عبدالعزيز بهدف: (أ) دراسة تأثير

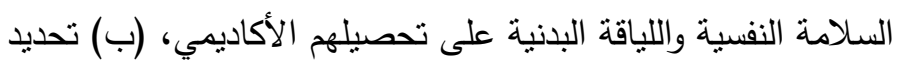

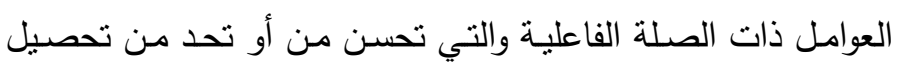

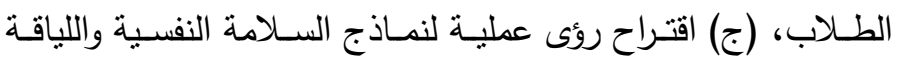
البدنية المثالية للطلاب السعوديين إذ يحتاج المخططون في المملكة لبيانات هذه الدراسات للتوفيق بين الخدمات المقدمة المرتبطة بالعملية

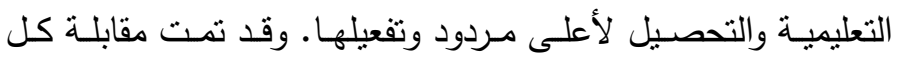

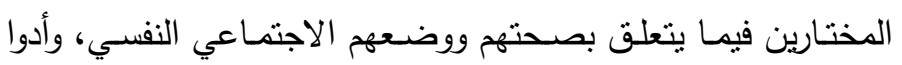
اختبار ذكاء وخضعوا لمقاييس اختبار لياقة تبعها اختبار بياناتهم الأكاديمية وتسجيل منوسط درجاتهم العامة.

وقد كثف تحليل الاختلاف الخـاص بتأثير (OV) متغيراً

للطلاب المختبرين على متوسط درجاتهم العامة أهمية لعشرين منها

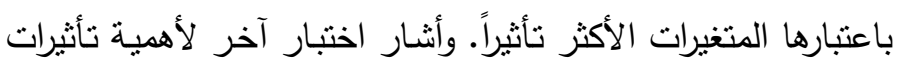

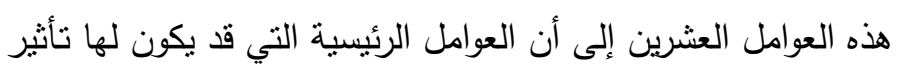

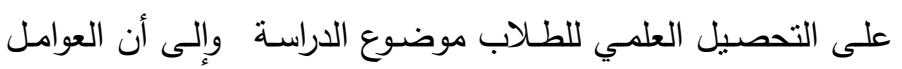


العلميـة الرئيسـية المؤثرة على قدرات التحصـيل الأكـاديمي للطلبـة

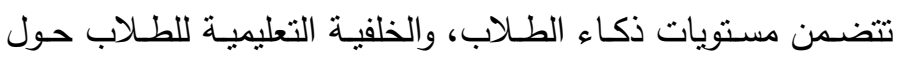
حفـظ وقـراءة القـرآن الكـريم، ودراســة اللغــة الإنجليزيــة واســتخدام

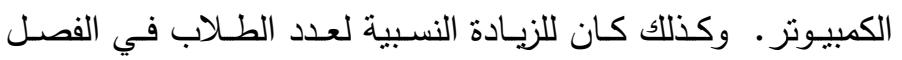
الدراسي تأثنير سلبي على متوسط درجاتهم العامـة، كما تمثل حاجة

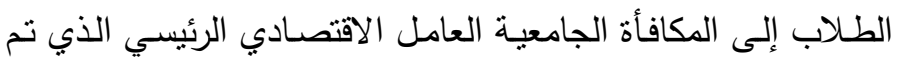

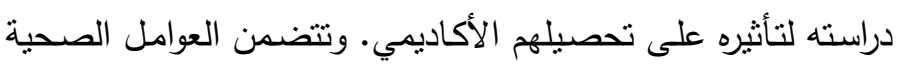

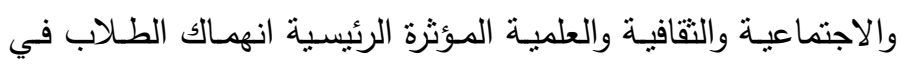

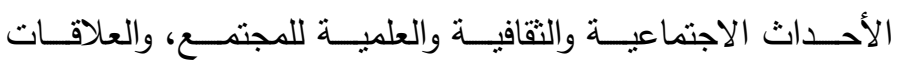

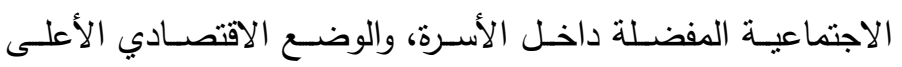

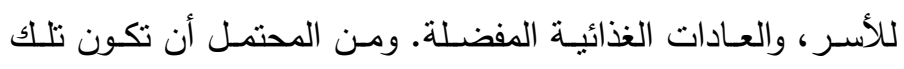

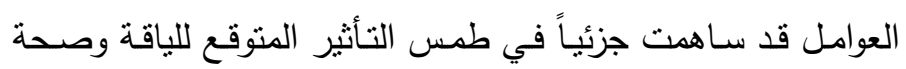

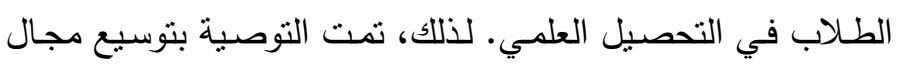

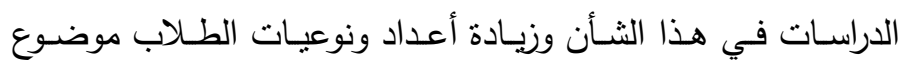

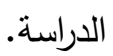

